\title{
Changes in the Forms of Cadmium with Time in Some Western Australian Soils
}

\author{
S. S. Mann and G. S. P. Ritchie
}

\begin{abstract}
Changes in the forms of Cd with time could affect its uptake by plants and hence potential toxicity to animals and humans. The effect of time on the forms of native and added Cd was studied in four West Australian soils which differed in their clay, hydrous oxide and organic matter content. Sequential extraction of soluble $(\mathrm{KCl})$, exchangeable $\left(\mathrm{BaCl}_{2}\right)$, bound to organic matter $(\mathrm{NaOCl})$, bound to oxides/clays (ammonium oxalate) and residual (concentrated acids) forms of $\mathrm{Cd}$ was carried out at different time intervals after the addition of $\mathrm{Cd}$.

The Cd that was added to the soils transformed with time to less soluble forms; the extent depending upon the type of soil. In addition, the rate of transformation in a particular type of soil was affected by both $\mathrm{pH}$ and rate of $\mathrm{Cd}$ addition. Soluble cadmium in the sandy soil decreased with time whereas the exchangeable form increased. The extent of the changes increased with increase in $\mathrm{pH}$. In the peaty sand at $\mathrm{pH} \leq 5$, exchangeable $\mathrm{Cd}$ increased apparently at the expense of soluble $\mathrm{Cd}$. At higher $\mathrm{pH}$ values, however, $\mathrm{Cd}$ bound to organic matter increased with time as exchangeable $\mathrm{Cd}$ decreased. In the lateritic podzolic soil (dominated by kaolinite), there was no effect of time on the forms of $\mathrm{Cd}$ at $\mathrm{pH}$ values $\leq 5$. At $\mathrm{pH} \geq 6$, the exchangeable form of $\mathrm{Cd}$ decreased whereas $\mathrm{Cd}$ bound to organic matter and residual $\mathrm{Cd}$ increased with time. In the yellow earth (dominated mainly by goethite), soluble $\mathrm{Cd}$ decreased with time at $\mathrm{pH}$ values $\leq 5$ and became a negligible fraction at $\mathrm{pH} 6$. Exchangeable $\mathrm{Cd}$ decreased with time at $\mathrm{pH}$ values $\geq 5$ whereas $\mathrm{Cd}$ bound to oxides and residual $\mathrm{Cd}$ increased with time at all the $\mathrm{pH}$ values.
\end{abstract}

\section{Introduction}

Cadmium (Cd) has accumulated in some Australian soils due to the application of phosphatic fertilizers to overcome phosphorus deficiencies in crops (Williams and David 1973). The extent of the build up of Cd varies with the type of soil, $\mathrm{Cd}$ content in the fertilizers and the management practices involved (Mortvedt et al. 1981; Tiller et al. 1984; Rothbaum et al. 1986; Barrow 1987; Alloway 1990; Mann and Ritchie 1993). Cadmium has been shown to adsorb onto soil surfaces very quickly with virtually no changes observed with time (Sidle and Kardos 1977; King 1988). In other studies, however, adsorption continued for longer periods of time (Brummer et al. 1988). The retention of $\mathrm{Cd}$ or any other metal by soils appears to be a multistep process involving an initial fast adsorption (from soil solution to external soil surface) followed by slow adsorption, i.e. diffusion 


\section{Yellow earth}
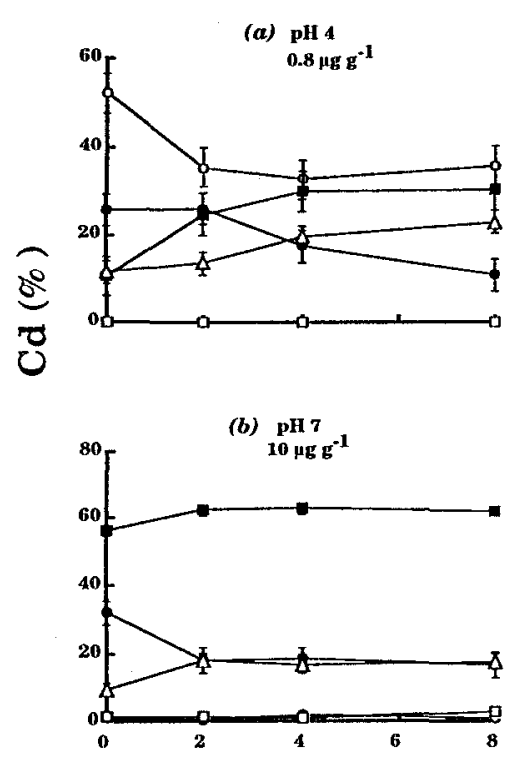

\section{Lateritic podzolic}
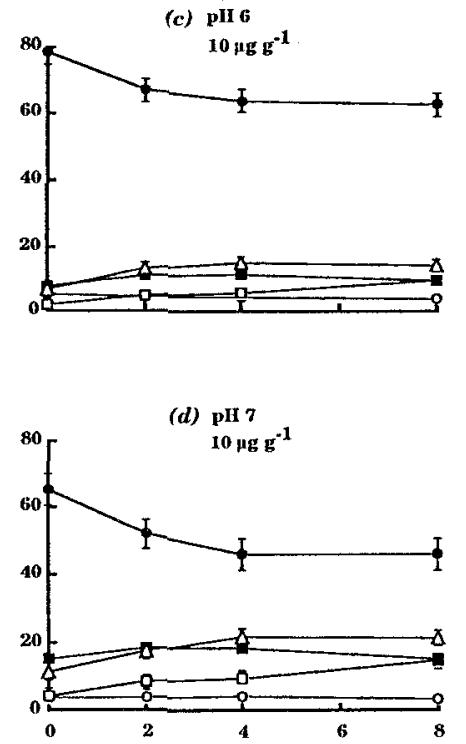

\section{Peaty sand}

(e) $\mathrm{pH} 4$

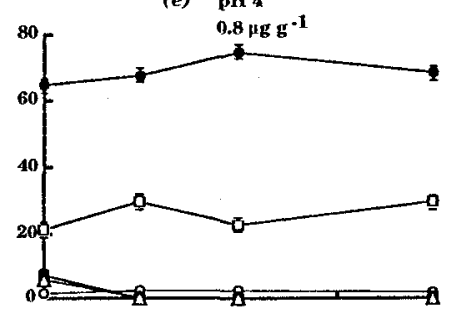

(f) $\quad \mathrm{pH} 7$

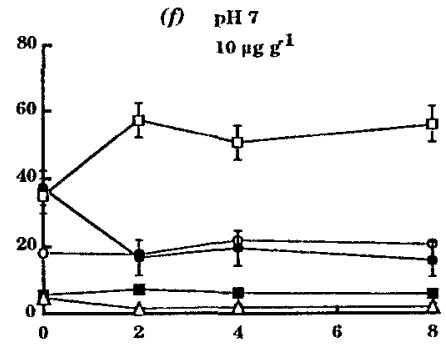

Siliceous sand

(g) pH 4

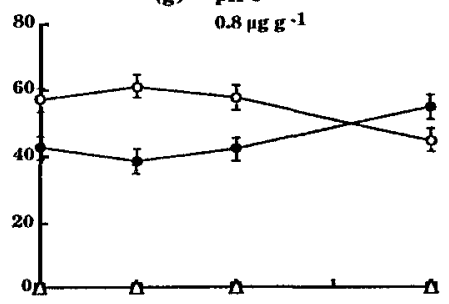

(h) $\mathrm{pH} 7$

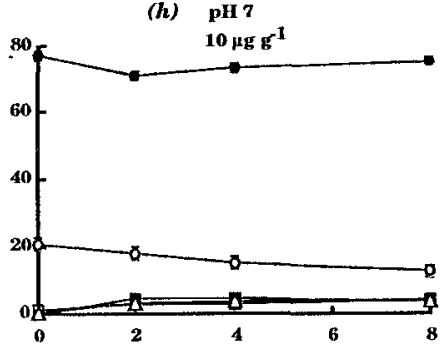

\section{Time (days)}

Fig. 1. Relationship between time and forms of Cd $[\%$ soluble $\mathrm{Cd}(\mathrm{O}), \%$ exchangeable Cd (O), \% Cd bound to organic matter ( $\square$ ), \% Cd bound

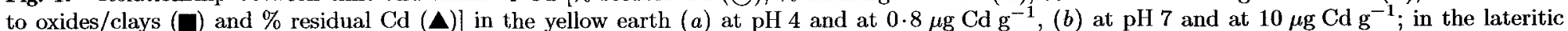
podzolic $(c)$ at $\mathrm{pH} 6$ and at $10 \mu \mathrm{g} \mathrm{Cd} \mathrm{g}^{-1},(d)$ at $\mathrm{pH} 7$ and at $10 \mu \mathrm{g} \mathrm{Cd} \mathrm{g}^{-1}$; in the peaty sand $(e)$ at $\mathrm{pH} 4$ and at $0.8 \mu \mathrm{g} \mathrm{Cd} \mathrm{g}^{-1},(f)$ at $\mathrm{pH} 7$ and

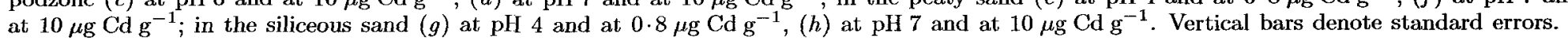


into pores of inner soil surfaces (Kinniburgh and Jackson 1981; Aringhieri et al. 1985; Brummer et al. 1988).

Most studies of the effect of time on $\mathrm{Cd}$ retention have not distinguished between the effect of time on $\mathrm{Cd}$ retention by different soil components. The changes in retention of $\mathrm{Cd}$ with time will depend on the type of components present in a soil and the factors that affect the retention by each component. Mann and Ritchie (1993) found that $\mathrm{pH}$ was a major factor that affected the extent of retention by different components which ultimately affected the proportion of the forms of $\mathrm{Cd}$ in each soil.

The effect of time on retention may have important implications for Cd uptake by plants and hence $\mathrm{Cd}$ accumulation in the food chain. If $\mathrm{Cd}$ moves into less available forms with time, there will be less danger of its uptake by plants (Brams and Anthony 1988; Bell et al. 1991). There is some evidence that $\mathrm{Cd}$ availability to plants decreases with time (Street et al. 1978).

The objective of this research was to study the effect of time on the forms of $\mathrm{Cd}$ extracted by a sequential extraction scheme at different $\mathrm{pH}$ values and at different rates of $\mathrm{Cd}$ addition in four soils. The soils were chosen according to their hydrous oxide, organic matter and clay contents.

\section{Materials and Methods}

\section{Soils}

The soils used in this study came from virgin sites and were a yellow earth, a lateritic podzolic, a peaty sand and a siliceous sand. They were described in detail by Mann and Ritchie (1993). Phosphorus fertilizers had not been applied to the soils previously and hence any $\mathrm{Cd}$ found in the unamended soils is referred to as native $\mathrm{Cd}$.

\section{Incubation Procedure}

A quantity of $200 \mathrm{~g}$ of each soil was taken and the soil solution $\mathrm{pH}$ was adjusted to $4 \cdot 0,5 \cdot 0$, 6.0 and 7.0 as described by Mann and Ritchie (1993). Cadmium was added as a $\mathrm{Cd}\left(\mathrm{NO}_{3}\right)_{2}$ solution to achieve $0,0.8,3 \cdot 2$ and $10 \cdot 0 \mu \mathrm{g} \mathrm{Cd} \mathrm{g}^{-1}$ and then incubated at $40 \pm 1^{\circ} \mathrm{C}$ (Mann and Ritchie 1993) for $0,2,4$ and 8 days. At the end of each incubation period, sufficient soil was removed from each treatment to carry out sequential extractions on three replicates. Each subsample was frozen until the extractions were carried out. A sequential extraction scheme (Mann and Ritchie 1993) was carried out on each subsample to estimate soluble Cd (extracted by $0.005 \mathrm{M} \mathrm{KCl}$ ), exchangeable $\mathrm{Cd}$ (extracted by $0.1 \mathrm{M} \mathrm{BaCl}_{2}$ ), Cd bound to organic matter (extracted by $5 \cdot 3 \% \mathrm{NaOCl}, \mathrm{pH} \approx 8 \cdot 5$ ), $\mathrm{Cd}$ bound to oxides/clay (extracted by ammonium oxalate solution) and residual $\mathrm{Cd}$ (extracted by concentrated acids).

\section{Analysis of $C d$}

Cadmium in different extracts was determined by flame atomic absorption spectrophotometry (FAAS) or by using a graphite furnace (GFAAS; Mann and Ritchie 1993). The accuracy of the method was tested by Mann (1993).

\section{Results}

The effect of time on the amount and percentage of total $\mathrm{Cd}(\% \mathrm{Cd})$ in each extract varied with the type of soil, $\mathrm{pH}$ and with rates of $\mathrm{Cd}$ addition. The general trends for each soil are summarized in Fig. 1. Cadmium extracted and \% $\mathrm{Cd}$ in each fraction varied with time in a similar manner and hence the results will be reported for \% $\mathrm{Cd}$ only. 


\section{Forms of Native $C d$}

In the absence of added $\mathrm{Cd}$, acid-extractable $\mathrm{Cd}$ was the only fraction observed in the yellow earth and lateritic podzolic soil and it did not change with time at any $\mathrm{pH}$. No native $\mathrm{Cd}$ was detectable in the peaty sand and siliceous sand.

\section{Forms of Added Cd}

\section{Yellow earth}

The $\% \mathrm{Cd}-\mathrm{KCl}$ decreased in the first 2 days of incubation at $\mathrm{pH} \leq 5$ for all the application rates studied (e.g. Figs $1 a$ and $1 b$ ). The $\% \mathrm{Cd}-\mathrm{BaCl}_{2}$ decreased with time at all $\mathrm{pH}$ values and at all rates except at $\mathrm{pH} 4$ where a decrease was only noticed in the presence of $0.8 \mu \mathrm{g} \mathrm{Cd} \mathrm{g}^{-1}$ (Figs $1 a$ and $1 b$ ). At all pH values, $\% \mathrm{Cd}-\mathrm{BaCl}_{2}$ tended to decrease over the complete incubation period at an application rate of $0.8 \mu \mathrm{g} \mathrm{g}^{-1}$ (e.g. Fig. 1a). At other rates, a significant decrease in $\% \mathrm{Cd}-\mathrm{BaCl}_{2}$ was noticed only up to the second day of incubation (Fig. 1b).

The $\% \mathrm{Cd}-\mathrm{NaOCl}$ was $<3 \%$ of total $\mathrm{Cd}$ and therefore considered negligible (Figs $1 a$ and $1 b)$. The $\% \mathrm{Cd}$-ammonium oxalate $(\% \mathrm{Cd}-\mathrm{AO}$ ) increased with time at all the $\mathrm{pH}$ values and at all the rates of $\mathrm{Cd}$ application (Figs $2 a$ and $2 b$ ). The rate of increase in \% Cd-AO decreased with increasing time, $\mathrm{pH}$ and application rate of $\mathrm{Cd}$. The maximum increase in $\% \mathrm{Cd}-\mathrm{AO}$ was observed within the first 2 days of incubation (Fig. $2 b$ ).

\section{Yellow earth}


\section{Time (days)}

Fig. 2. Relationship between time and (a) \% Cd bound to oxides; (c) \% residual Cd at pH 4 and at $\mathrm{Cd}$ application rates $0.8 \mu \mathrm{g} \mathrm{Cd} \mathrm{g}^{-1}(\mathrm{O}), 3 \cdot 2 \mu \mathrm{g} \mathrm{Cd} \mathrm{g}^{-1}(\mathbf{O})$, and $10 \mu \mathrm{g} \mathrm{Cd} \mathrm{g}^{-1}(\square)$; and $(b) \% \mathrm{Cd}$ bound to oxides; $(d) \%$ residual $\mathrm{Cd}$ at $10 \mu \mathrm{g} \mathrm{Cd} \mathrm{g^{-1 }}$ rate and at $\mathrm{pH}$ values 4 $(\bigcirc), 5(0), 6(\square)$ and $7(\square)$ in the yellow earth. Vertical bars denote standard errors. 
The \% Cd-acid extractable tended to increase with time at all the rates and at all the $\mathrm{pH}$ values (Figs $2 c$ and $2 d$ ). At $\mathrm{pH} 4$, the extent of increase with time decreased with increasing application rate (Fig. 2c). At $\mathrm{Cd}$ application rates $>0.8 \mu \mathrm{g} \mathrm{g}^{-1}$, the rate of increase in $\% \mathrm{Cd}$-acid extractable decreased with time and became negligible after 2 days (Fig. $2 d$ ).

\section{Lateritic podzolic}

The amount of all the forms of $\mathrm{Cd}$ at $\mathrm{pH} 4$ and 5 did not change with time at any of the rates of $\mathrm{Cd}$ application (data not shown). At pH 6 and 7, however, changes in concentration of all forms of $\mathrm{Cd}$ were observed with time except for $\% \mathrm{Cd}-\mathrm{KCl}$ and $\% \mathrm{Cd}-\mathrm{AO}$ (Figs $1 c$ and $1 d$ ). The $\% \mathrm{Cd}-\mathrm{BaCl}_{2}$ decreased curvilinearly by $15-20 \%$ after 8 days at $\mathrm{pH} \geq 6$ and at $\mathrm{Cd}$ rates $\geq 3 \cdot 2 \mu \mathrm{g} \mathrm{g}^{-1}$ (e.g. Fig. $3 a$ ). At $0.8 \mu \mathrm{g} \mathrm{g}^{-1} \mathrm{Cd}$ application, and at $\mathrm{pH} 6$ and $7, \% \mathrm{Cd}-\mathrm{BaCl}_{2}$ varied inconsistently with time. The $\% \mathrm{Cd}-\mathrm{NaOCl}$ increased $5-10 \%$ after 8 days incubation at all the rates of $\mathrm{Cd}$ application at $\mathrm{pH} 6$ and 7 (e.g. Fig. $3 b$ ). At $\mathrm{pH} 6$, an increase in \% Cd-acid extractable was observed up to the second day of incubation at all the rates of $\mathrm{Cd}$ application (Fig. $3 \mathrm{c}$ ). At $\mathrm{pH} 7$, a linear increase with time in $\% \mathrm{Cd}$ from 25 to $40 \%$ was observed at $0.8 \mu \mathrm{g} \mathrm{g}^{-1} \mathrm{Cd}$ rate whereas, at other rates, an increase of nearly $10 \%$ was observed up to the fourth day and thereafter remained constant (Fig. $3 d$ ).

\section{Lateritic podzolic}

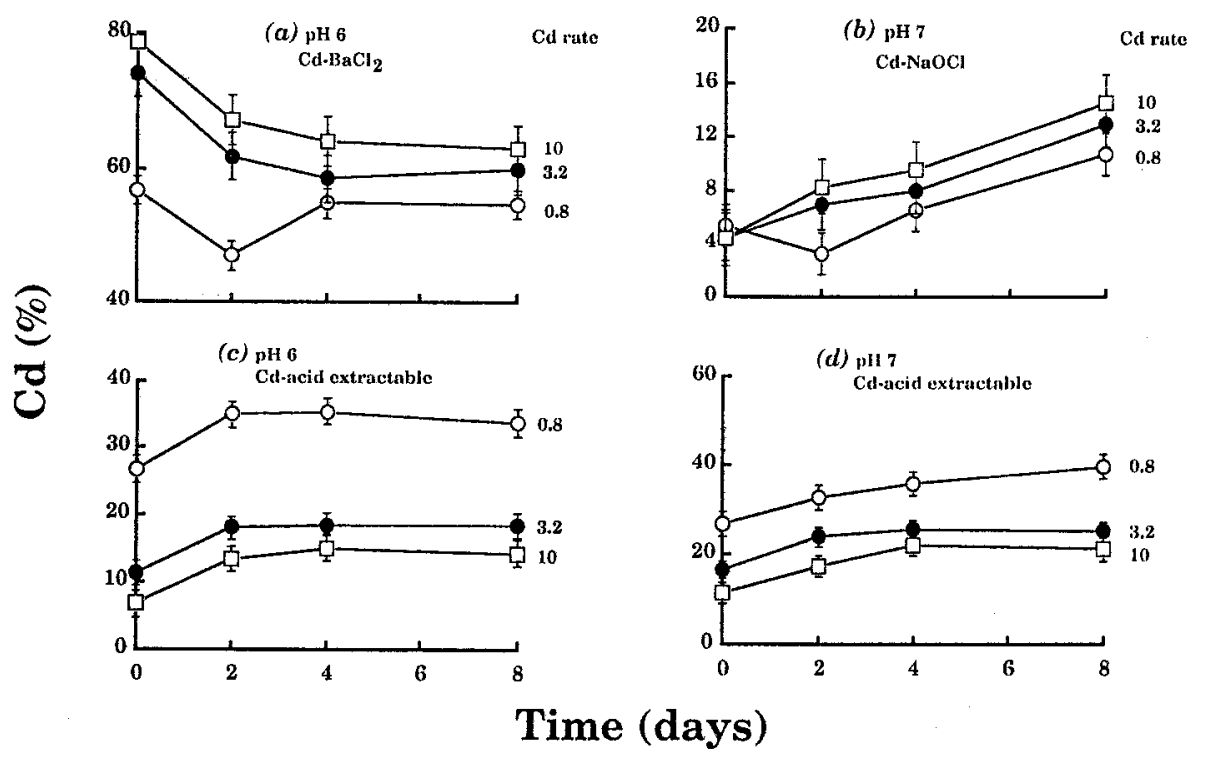

Fig. 3. Relationship between time and (a) \% exchangeable $\mathrm{Cd}$ at $\mathrm{pH} 6,(b) \% \mathrm{Cd}$ bound to organic matter at $\mathrm{pH} 7,(c) \%$ residual $\mathrm{Cd}$ at $\mathrm{pH} 6$ and $(d) \%$ residual $\mathrm{Cd}$ at $\mathrm{pH} 7$ at $\mathrm{Cd}$ application rates $0.8 \mu \mathrm{g} \mathrm{Cd} \mathrm{g}^{-1}(\mathrm{O}), 3.2 \mu \mathrm{g} \mathrm{Cd} \mathrm{g}^{-1}(\mathrm{O})$ and $10 \mu \mathrm{g} \mathrm{Cd} \mathrm{g}^{-1}$ (a) in the lateritic podzolic soil. Vertical bars denote standard errors. 


\section{Peaty sand}

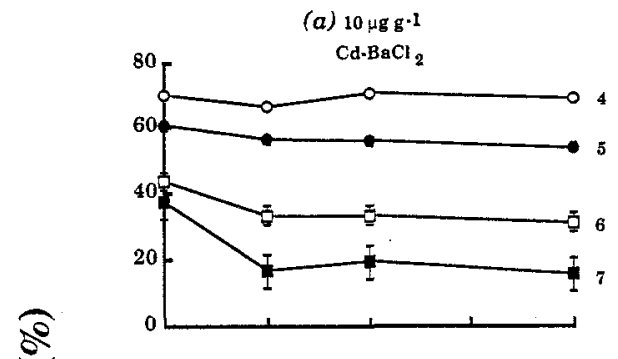

Fig. 4. Relationship between time and (a) \% exchangeable $\mathrm{Cd},(b) \% \mathrm{Cd}$ bound to organic matter at $10 \mu \mathrm{g} \mathrm{Cd} \mathrm{g}^{-1}$ application rate and at $\mathrm{pH}$ values $4(\mathrm{O}), 5(\mathbf{O}), 6(\square)$ and $7(\boldsymbol{\square})$ in the peaty sand. Vertical bars denote standard

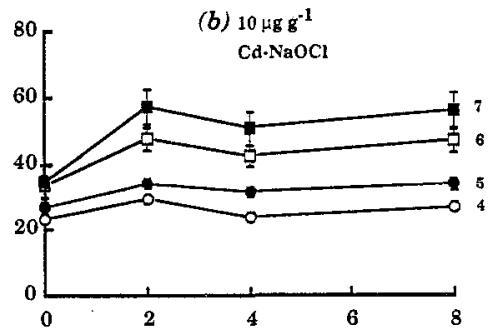
errors.

\section{Time (days)}

\section{Siliceous sand}

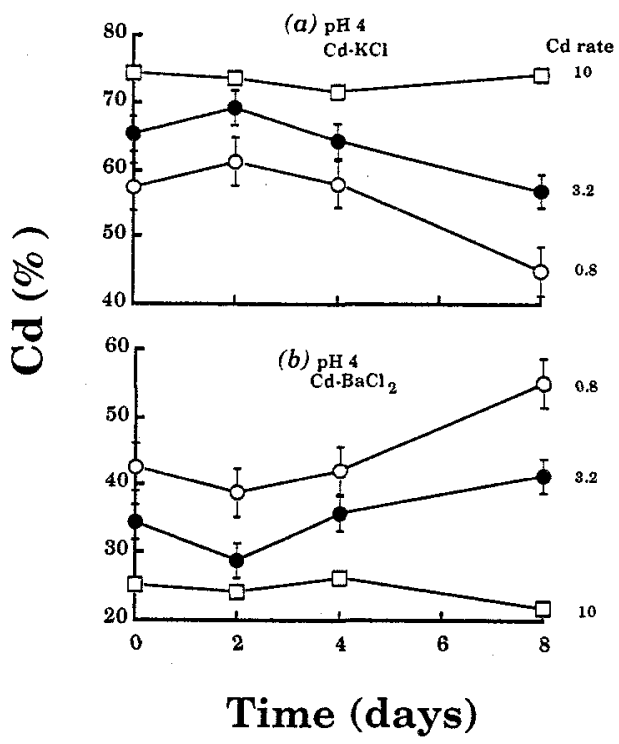

Fig. 5. Relationship between time and (a) \% soluble $\mathrm{Cd}$ and (b) \% exchangeable $\mathrm{Cd}$ at $\mathrm{pH} 4$ and at $\mathrm{Cd}$ application rates of $0.8 \mu \mathrm{g} \mathrm{Cd} \mathrm{g}^{-1}(\mathrm{O}), 3 \cdot 2 \mu \mathrm{g} \mathrm{Cd}^{-1}(\mathbf{)})$, and $10 \mu \mathrm{g} \mathrm{Cd} \mathrm{g}^{-1}(\mathbf{\square})$ in the siliceous sand Vertical bars denote standard errors.

\section{Peaty sand}

The $\% \mathrm{Cd}-\mathrm{KCl}$ tended to increase slightly $(<10 \%)$ with time at all the rates of $\mathrm{Cd}$ application and at all the $\mathrm{pH}$ values except at $\mathrm{pH} 4$ (Figs $1 e$ and $1 f$ ). The $\% \mathrm{Cd}-\mathrm{BaCl}_{2}$ decreased and $\% \mathrm{Cd}-\mathrm{NaOCl}$ increased with time up to the second 
day at all the rates of $\mathrm{Cd}$ application at $\mathrm{pH}>5$ (e.g. Figs $4 a$ and $4 b$ ). The $\%$ $\mathrm{Cd}-\mathrm{AO}$ and the $\% \mathrm{Cd}$-acid extractable were a small fraction $(<10 \%)$ of the total $\mathrm{Cd}$ applied to the soil and did not change significantly with time.

\section{Siliceous sand}

The \% Cd in the $\mathrm{KCl}$ extract decreased with time at all the $\mathrm{pH}$ values and at all the rates except at $\mathrm{pH} 4$ and at an application rate of $10 \mu \mathrm{g} \mathrm{Cd} \mathrm{g}^{-1}$ (Fig. 5a). At $\mathrm{pH} 4$, the $\% \mathrm{Cd}-\mathrm{KCl}$ tended to decrease after 2 days of incubation at $\mathrm{Cd}$ rates $\leq 3 \cdot 2 \mu \mathrm{g} \mathrm{g}^{-1}$ (Fig. $5 a$ ). The $\% \mathrm{Cd}-\mathrm{BaCl}_{2}$ increased slightly with time at $\mathrm{pH} 4$ at times $>2$ days and at $\mathrm{Cd}$ application rates $\leq 3 \cdot 2 \mu \mathrm{g} \mathrm{g}^{-1}$ (Fig. $5 b$ ). At $10.0 \mu \mathrm{g} \mathrm{g}^{-1}$ application rate, no effect of time was observed at any $\mathrm{pH}$. No change in the $\mathrm{NaOCl}$, ammonium oxalate and acid-extractable $\mathrm{Cd}$ was observed at any $\mathrm{pH}$ values except at $\mathrm{pH} 7$ where only a slight increase $(<5 \%)$ in these forms was observed at all the rates of $\mathrm{Cd}$ application (Figs $1 \mathrm{~g}$ and $1 \mathrm{~h}$ ).

\section{Discussion}

There was a general decline in the more soluble forms of $\mathrm{Cd}$ and an increase in the less soluble forms as time progressed in each soil except the peaty sand. The extent and rate of change with time of the amount of $\mathrm{Cd}$ in each form depended on the type of adsorbing surface, $\mathrm{pH}$ and application rate of $\mathrm{Cd}$. In general, the more sites available for retention of $\mathrm{Cd}$, the more quickly the rate of change of $\mathrm{Cd}$ in a particular form approached zero. In the yellow earth, for example, the rate of change approached zero within 2 days at $\mathrm{pH} 7$. At $\mathrm{pH} 4$, there would have been fewer negatively charged sites and the rate of change of $\mathrm{Cd}$, in almost all the forms, continued for a longer period of time.

For a particular soil, the transformation also varied with the rate of $\mathrm{Cd}$ addition. In the yellow earth, for example, the transformation of $\mathrm{Cd}$ to the form bound by oxides and to residual forms continued for a longer period of time at lower rates of $\mathrm{Cd}$ application than at higher rates (Figs $2 e$ and $2 g$ ). This could be due to the difference in the concentration gradient from the surface into an internal pore, created by different rates of $\mathrm{Cd}$ addition. At lower rates, the concentration gradient would be lower than that at higher rates and hence transformation of $\mathrm{Cd}$ from one form to another was slower.

The extent and rate of formation of one form will depend upon the rate of formation of all the other forms, as each reaction will be removing $\mathrm{Cd}$ from solution and hence will be affecting the solution concentration to different extents. However, in situations where there was negligible soluble Cd (e.g. in yellow earth and peaty sand at $\mathrm{pH}>5$ ), a decrease in the amount of $\mathrm{Cd}$ in the exchangeable form occurred (e.g. Figs $2 d$ and $6 c$ ) as more strongly bound $\mathrm{Cd}$ increased. In the lateritic podzolic soil at $\mathrm{pH}<5$, most of the $\mathrm{Cd}$ was in an exchangeable form and the remainder was soluble. At higher $\mathrm{pH}$ values, a decrease in the exchangeable form of $\mathrm{Cd}$ and an increase in residual and that bound to organic matter was observed as time progressed, possibly due to the development of more strongly binding sites on the edges of kaolinite and on organic matter (Figs $3 a$ and $3 b$ ).

In the yellow earth soil, the soluble and the exchangeable forms of $\mathrm{Cd}$ decreased with time, whereas $\mathrm{Cd}$ bound to oxides and residual $\mathrm{Cd}$ increased. Goethite was the major adsorption component in this soil. The rate of change of $\mathrm{Cd}$ with 
time was affected by $\mathrm{pH}$ and the rate of $\mathrm{Cd}$ addition. A decrease in soluble $\mathrm{Cd}$ with time was observed at $\mathrm{pH} \leq 5$ only, presumably because of a limited number of adsorption sites present at lower $\mathrm{pH}$ values. Evidence for a limited number of sites can also be seen from the increase in $\% \mathrm{Cd}$ in the soluble form (\% $\mathrm{Cd}-\mathrm{KCl}$ ) as the application rate of $\mathrm{Cd}$ increased. At $\mathrm{pH} 6$ and 7 , soluble $\mathrm{Cd}$ was almost negligible $(<2 \%)$ at all the rates of $\mathrm{Cd}$ addition, presumably because $\mathrm{Cd}$ is adsorbed at negatively charged sites which increase in number with $\mathrm{pH}$ and there were sufficient sites to adsorb almost all the $\mathrm{Cd}$ added, even at the highest rate of $\mathrm{Cd}$ application. Not only the soluble $\mathrm{Cd}$ declined with time, but even exchangeable $\mathrm{Cd}$ started to decline at higher $\mathrm{pH}$ values. Presumably, variable-charged negative sites developed at $\mathrm{pH} \geq 5$ and bound $\mathrm{Cd}$ by forces other than coulombic and/or became less accessible. Tiller et al. (1984) in their study also observed the transfer of non-specifically bound forms to specifically bound forms.

In the lateritic podzolic soil, time had no effect on the amount of $\mathrm{Cd}$ in any of the forms at $\mathrm{pH} \leq 5$ and the two major forms of $\mathrm{Cd}$ were soluble and exchangeable. The reaction of $\mathrm{Cd}$ with the kaolinitic clays was rapid as might be expected when exchange sites are mainly found on external surfaces. At $\mathrm{pH} 6$ and 7 , however, exchangeable $\mathrm{Cd}$ decreased with time while residual $\mathrm{Cd}$ tended to increase, reflecting a small increase in variable charged sites on the edges of kaolinite which can bond $\mathrm{Cd}$ by stronger forces than just coulombic attraction. Cadmium bound by organic matter also increased slightly with time which could be attributed to the development of some additional specific adsorption sites within the organic matter particles rather than at the surfaces. The transformation of exchangeable $\mathrm{Cd}$ to other forms (residual and bound to organic matter) was affected by the rate of $\mathrm{Cd}$ addition which also reflects the formation of a limited number of specific adsorption sites. At $\mathrm{pH}$, the transformation of exchangeable $\mathrm{Cd}$ to residual $\mathrm{Cd}$ continued up to the fourth day of incubation whereas, at $\mathrm{pH} 7$, the transformation continued for a longer period of time, especially at the lower rate of $\mathrm{Cd}$ addition. A possible explanation for this may be that the strength of binding by exchangeable and residual sites becomes more similar at higher $\mathrm{pH}$ and hence there is less transformation of the exchangeable forms to the residual forms.

Time had no effect on any of the forms of $\mathrm{Cd}$ in the peaty sand at $\mathrm{pH}<5$, presumably because $\mathrm{Cd}$ reacts with exchange sites (the major form) very rapidly. At $\mathrm{pH}$ values $\geq 5$, soluble $\mathrm{Cd}$ and $\mathrm{Cd}$ bound to organic matter increased with time, whereas exchangeable $\mathrm{Cd}$ decreased, suggesting that organic matter became the main adsorption component of the soil due to the development of $\mathrm{pH}$-dependent adsorption sites. The effect of time on the forms of $\mathrm{Cd}$ in the peaty sand was affected the least by the $\mathrm{Cd}$ application rate, indicating that there were enough sites on the organic matter to adsorb most of the $\mathrm{Cd}$ applied at $\mathrm{pH} \geq 5$. The reactions tended to be faster initially and then slowed down with time. Aringhieri et al. (1985) observed that $80 \%$ of adsorption took place within $10 \mathrm{~min}$ of $\mathrm{Cd}$ addition to a soil containing high organic matter $(14 \cdot 2 \%)$ and high clay content $(60 \%)$. A slight increase in the soluble form of $\mathrm{Cd}$ at $\mathrm{pH} 7$ was also observed with time which is possibly due to the slow dissolution of organic matter at higher $\mathrm{pH}$ values, subsequently releasing $\mathrm{Cd}$ into the soil solution (Borggaard 1979).

In the siliceous sand, the soluble form of $\mathrm{Cd}$ decreased with time, whereas the exchangeable form of $\mathrm{Cd}$ increased. Most of the $\mathrm{Cd}$ applied to the siliceous sand 
stayed in soluble and/or exchangeable forms $(>95 \%)$ at all the $\mathrm{pH}$ values because of the soil's limited adsorption capacity due to the absence of adsorption components (i.e. organic matter, oxides and clays). At $\mathrm{pH} \mathrm{4,} \mathrm{no} \mathrm{change} \mathrm{in} \mathrm{these} \mathrm{forms} \mathrm{with}$ time was observed at the highest rate of $\mathrm{Cd}$ application because of a limited number of exchange sites (Figs $8 a$ and $8 c$ ). At application rates $\leq 3 \cdot 2 \mu \mathrm{g} \mathrm{g}^{-1}$, the decrease in soluble $\mathrm{Cd}$ and the concomitant increase in exchangeable $\mathrm{Cd}$ at all $\mathrm{pH}$ values suggested that there were sufficient exchange sites for the amount of $\mathrm{Cd}$ applied. At the highest rate, a decrease in soluble $\mathrm{Cd}$ with time was noticed at $\mathrm{pH}>5$, presumably because sufficient sites were only available above this $\mathrm{pH}$. However, the extent of the decrease did not increase as $\mathrm{pH}$ rose from 5 to 7 (i.e. the number of sites increased), possibly because the rate of exchange is $\mathrm{pH}$ dependent and increased with $\mathrm{pH}$ due to less competition with cations such as $\mathrm{H}^{+}$.

In soils where $\mathrm{Cd}$ was not added but was already present as native $\mathrm{Cd}$ (the yellow earth and lateritic podzolic soils), most of it was extracted as residual $\mathrm{Cd}$ (i.e. 0.07 and $0.14 \mu \mathrm{g} \mathrm{g}^{-1}$ respectively) and no change in any of the forms of $\mathrm{Cd}$ with time was observed. This suggested that native $\mathrm{Cd}$ was derived from the parent material where it was either entrapped/occluded in the phyllosilicate and sesquioxide minerals (Rudd et al. 1984). Alternatively, the yellow earth and lateritic podzolic soils were contaminated with $\mathrm{Cd}$ from a source which slowly diffused into less accessible sites with time (Brummer et al. 1988; Barrow et al. 1989).

The amounts of soluble and exchangeable $\mathrm{Cd}$ are indications of the most labile or bioavailable forms in the soil (LeClaire et al. 1984) and, hence, their transformation to other forms with time suggested a decrease in availability of Cd. This is in agreement with the findings of Street et al. (1978) who found that increasing the incubation time decreased the availability of $\mathrm{Cd}$ to plants. However, in soils such as the siliceous sand (irrespective of time since $\mathrm{Cd}$ application), the transformation of soluble $\mathrm{Cd}$ will be restricted to exchangeable and precipitated forms only.

\section{Conclusions}

An increase in the time of contact of $\mathrm{Cd}$ decreased the soluble and the exchangeable forms of $\mathrm{Cd}$ in all the soils except the siliceous sand. These changes have the potential to decrease the risk of $\mathrm{Cd}$ loss to groundwater by leaching and the risk of $\mathrm{Cd}$ uptake by plants. However, the rate and extent of the decrease in soluble and exchangeable forms of $\mathrm{Cd}$ with time (and hence, the risk) depended upon the type and relative proportion of the adsorption surfaces present in the soil, $\mathrm{pH}$ and the rate of $\mathrm{Cd}$ addition.

\section{References}

Alloway, B. J. (1990). Soil processes and the behaviour of metals. In 'Heavy Metals in Soils'. (Ed. B. J. Alloway.) pp. 7-27. (Blackie and Sons: New York.)

Aringhieri, R., Carrai, P., and Petruzzelli, G. (1985). Kinetics of $\mathrm{Cu}^{2+}$ and $\mathrm{Cd}^{2+}$ adsorption by an Italian soil. Soil Science 139, 197-204.

Barrow, N. J. (1987). Reactions with variable charge soils. Fertilizer Research 14, 1-100.

Barrow, N. J., Gerth, J., and Brummer, G. W. (1989). Reaction kinetics of the adsorption and desorption of nickel, zinc and cadmium by goethite. II. Modelling the extent and rate of reaction. Journal of Soil Science 40, 437-50. 
Bell, P. F., James, B. R., and Chaney, R. L. (1991). Heavy metal extractability in long-term sewage sludge and metal salt-amended soils. Journal of Environmental Quality 20, 481-86.

Borggaard, O. K. (1979). Selective extraction of amorphous iron oxides by EDTA from a Danish sandy loam. Journal of Soil Science 30, 727-34.

Brams, E., and Anthony, W. (1988). Residual cadmium in a soil profile and accumulation in wheat grain. Plant and Soil 109, 3-8.

Brummer, G., Gerth, J., and Tiller, K. G. (1988). Reaction kinetics of the adsorption and desorption of $\mathrm{Ni}, \mathrm{Zn}$ and $\mathrm{Cd}$ by goethite. 1. Adsorption and diffusion of metals. Journal of Soil Science 39, 37-51.

King, L. D. (1988). Retention of cadmium by several soils of southeastern United States. Journal of Environmental Quality 17, 246-50.

Kinniburgh, D. G., and Jackson, M. L. (1981). Cation adsorption by hydrous metal oxides and clays. In 'Adsorption of Inorganics at Solid-Liquid Interphases'. (Eds M. A. Anderson and A. S. Rubin.) pp. 91-160. (Ann Arbor Science: Michigan.)

LeClaire, J. P., Chang, A. C., Levesque, C. S., and Sposito, G. (1984). Trace metal chemistry in arid-zone field soils amended with sewage sludge: iv. Correlations between zinc and uptake and extracted soil zinc fractions. Soil Science Society of America Journal 48, 509-13.

Mann, S. S. (1993). Forms of cadmium in soils of Western Australia. Ph.D. Thesis, The University of Western Australia.

Mann, S. S., and Ritchie, G. S. P. (1993). The effect of $\mathrm{pH}$ on the forms of cadmium in four West Australian soils. Australian Journal of Soil Research 31, 255-70.

Mortvedt, J. J., Mays, D. A., and Osborn, G. (1981). Uptake by wheat of cadmium and other heavy metal contaminants in phosphatic fertilizers. Journal of Environmental Quality 10, 193-97.

Rothbaum, H. P., Goguel, R. L., Johnston, A. E., and Mattingly, G. E. G. (1986). Cadmium accumulation in soils from long-continued applications of superphosphate. Journal of Soil Science 37, 99-107.

Rudd, T., Sterritt, R. M., and Lester, J. N. (1984). Formation and conditional stability constants of complexes formed between heavy metals and bacterial extracellular polymers. Water research $18,379-84$.

Sidle, R. C., and Kardos, L. T. (1977). Adsorption of copper, zinc, and cadmium by a forest soil. Journal of Environmental Quality 6, 313-17.

Street, J. J., Sabey, B. R., and Lindsay, W. L. (1978). Influence of pH, phosphorus, cadmium, sewage sludge, and incubation time on the solubility and plant uptake of cadmium. Journal of Environmental Quality 7, 286-90.

Tiller, K. G., Gerth, J., and Brummer, G. (1984). The sorption of Cd, Zn, and Ni by soil clay fractions. Procedure for partition of bound forms and their interpretation. Geoderma 34, $1-16$.

Williams, C. H., and David, D. J. (1973). The effect of superphosphate on the cadmium content of soils and plants. Australian Journal of Soil Research 11, 43-56. 